ANNA BudZiaK

Uniwersytet Jagielloński

Katedra Ukrainistyki

\title{
Zapożyczenia polskie w materiale ukraińskim XIX-wiecznego ukraińsko-polskiego słownika frazeologicznego Iwana Wahylewycza
}

Słowa klucze: leksykografia ukraińska, frazeologia ukraińska, dialektologia ukraińska, zapożyczenia, Iwan Wahylewycz, Ruska Trójca

Iwan Wahylewycz (1811-1866) to jedna z najważniejszych postaci związanych z odrodzeniem narodowym Ukraińców w Galicji, współtwórca tzw. „Ruskiej Trójcy” - ugrupowania, które zapoczątkowało rozwój nowożytnej literatury galicyjskich Ukraińców, nową epokę w kształtowaniu się ich świadomości narodowej, i któremu nie były obojętne także zagadnienia ściśle językowe. Z prac językoznawczych lwowskiego uczonego należy wymienić najważniejsze, które dotyczą jego rodzimego języka - rękopiśmienne Rozprawy o języku południowo-ruskim (Wahylewycz, Rozprawy...) i Grammatykę języka małoruskiego w Galicii (Wagilewicz 1845). Wspomnijmy też, że spora część jego badań została poświęcona słownikarstwu. I. Wahylewycz zapisał się w dziejach językoznawstwa ukraińskiego jako jeden z pierwszych poważniejszych leksykografów. Spod jego pióra wyszły: słowniczki gwar huculskich, bojkowskich i łemkowskich, dodane do własnych artykułów autora z dziedziny etnografii (Wahylewič 1841, Вагилевич 1965, 1978, Wahylewycz 1838-1839, 1842, 1844, 1855), dwa warianty Idyotykonu - słownika ukraińsko-niemiecko-łacińskiego z licznymi paralelami z innych języków 
słowiańskich (głównie z języka polskiego) (Wahylewycz, Idyotykon...) oraz Idyotyzmy - słownik frazeologiczny ukraińsko-polski (Дзендзелівський 1979). Idyotykon i Idyotyzmy to dodatki do wspomnianych wyżej Rozpraw o języku południoworuskim. Autor wymienionych rejestrów ułożył również Дакійський словник, zawierający 765 wyrazów mołdawskich zapisanych cyrylicą i przetłumaczonych na język polski, dołączony do jego pracy Nauka języka dacko-romańskiego (Семчинский 1970). Nadmieńmy również, że był on jednym ze szczególnie zasłużonych redaktorów drugiego wydania słownika S. B. Lindego ${ }^{1}$. Nie sposób też nie wspomnieć tutaj próby opisu zapożyczeń w języku ukraińskim podjętej przez I. Wahylewycza, a zamieszczonej w Rozprawach... (Дзендзелівський 2000).

Prace lwowskiego leksykografa świadczą o jego rozległych zainteresowaniach językowych, zacięciu naukowym, niezłej znajomości osiągnięć językoznawstwa i obeznaniu ze studiami filologicznymi powstającymi w tamtym okresie; ilustrują one także poziom wiedzy językoznawczej i metody XIX-wiecznych badań lingwistycznych. Należy jednak przypomnieć, że ów pasjonujący się rodzimym językiem i Słowiańszczyzną erudyta nie miał przygotowania filologicznego i swój zasób wiadomości z tej dziedziny wzbogacał jako samouk. Jego studia nie były wolne od błędów, niekiedy budziły kontrowersje, część z nich ma charakter szkicowy, fragmentaryczny, niemniej jednak dla badaczy języka ukraińskiego i językoznawstwa słowiańskiego pierwszej połowy XIX w. przedstawiają one dużą wartość.

Ukraińsko-polski słownik frazeologiczny I. Wahylewycza, zatytułowany Idyotyzmy, został zestawiony w latach 40 . XIX w., a opublikowany dopiero w 1979 r. przez J. Dzendzeliwskiego razem z krótkim komentarzem tegoż badacza. Omawiany tutaj zbiór liczy 240 przykładów. Z punktu widzenia ukraińskiej leksykografii frazeologicznej dobór materiału zebranego w opisywanym zbiorku jest szczególnie interesujący, ponieważ nie zawiera przysłów, które stanowią wielką część tego typu prac powstałych w XIX w. Idyotyzmy I. Wahylewycza, jak zdecydowana większość rejestrów jednostek frazeologicznych tego czasu, sporządzone zostały w porządku alfabetycznym. Każde ukraińskie hasło ma polski odpowiednik. Należy podkreślić, że polskie ekwiwalenty nie we wszystkich przypadkach są frazeologizmami, często jest

1 Informacje o innych pracach I. Wahylewycza dotyczących języka polskiego zostały zamieszczone w artykule (Дзендзелівський 1981). 
to tylko wolne thumaczenie znaczenia utartego ukraińskiego połączenia wyrazowego. W większości wypadków jako hasła słownikowe autor prezentuje krótkie zdania - ilustracje użyć poszczególnych jednostek. Poważnym niedociągnięciem pracy jest brak objaśnień podanych przykładów i informacji o miejscu, gdzie zostały zapisane, a także - szczególnie nietrafne w słowniku zawierającym materiał dialektalny - zastosowanie przez autora pisowni etymologicznej. Źródłem, z którego I. Wahylewycz czerpał materiał do zbiorku istotnie uzupełniającego naszą wiedzę o frazeologii południowo-zachodnich gwar ukraińskich 1. poł. XIX w., był język mówiony mieszkańców Galicji. Warto podkreślić, że autor umieścił go razem z Idyotykonem w swoich Rozprawach... Można zatem przypuszczać, że zestawił zbiór w celu pokazania specyfiki języka ukraińskiego, gdyż we wprowadzeniu do Idyotykonu zawarł informację, iż unikał zamieszczania w jego rejestrze elementów zapożyczonych. Jak wykazała analiza Idiotyzmów, nie udało mu się jednak ominać, wśród charakterystycznych (według niego) ustalonych ukraińskich związków wyrazowych, zapożyczeń z języka polskiego.

Niniejszy artykuł nie ma na celu wskazanie wszystkich elementów pochodzących z języka polskiego, zawartych w badanym zbiorze, choćby z tego względu, że w wypadku tak bliskich języków często trudno stwierdzić, czy jakieś zjawisko językowe, znaczenie, forma wykształciły się na tym lub innym gruncie, czy też rozwijały się niezależnie od siebie w kilku językach. Poniżej przedstawiono jedynie jednostki zaczerpnięte z Idyotyzmów, zawierające komponenty, których polskie pochodzenie można uznać za pewne lub bardzo prawdopodobne. W udowodnieniu polskich korzeni pomocne były wykorzystane w analizie liczne ukraińskie i polskie źródła leksykograficzne, które jednocześnie unaoczniają, jak osobliwie autor omawianego zestawienia niekiedy przedstawiał swój materiał. Wyodrębniono następujące jednostki, które zawierają elementy polskiego pochodzenia ${ }^{2}$ :

Ecmь всего въ бродв (до воли).- Jestwszystko w dostatku.

W języku ukraińskim funkcjonuje przysłówek доволі o znaczeniu takim, jakie przypisał mu I. Wahylewycz, udokumentowany zarówno w słownikach historycznych, jak i tych, które zawierają leksykę współczesną, np. : доволи,

2 Analizowane jednostki zaczerpnięto z przywoływanej wcześniej pracy J. Dzendzeliwskiego (Дзендзелівський 1979). 
доволь 'досить, довольно; досхочу’ (ISUM VIII: 75); (SUM II: 337). Nie zostało jednak nigdzie poświadczone używanie w takim znaczeniu formy вбрі ${ }^{3}$, która jest notowana jedynie ze znaczeniem 'по дну річки, ставу, озера і т. ін. в неглибокому місці; бродом (іти, їхати)', np. (SUM I: 301). Natomiast w polskich źródłach, starszych i współczesnych, jest rejestrowane takie znaczenie, jak u I. Wahylewycza, np.: w bród, m.in. 'obficie, zbytecznie, po uszy’ (Na tym bankiecie wszędy w bród wszystkiego) (Linde I, 1: 168); w bród 'obficie, po pas, po uszy' (Warsz. I: 210; SJP I: 202-203).

На брязгъ вергло.-Zaczęło świtać.

Połączenie wyrazowe łączy zapożyczoną z polskiego formę брязг i czasownik вергти. Jak słusznie twierdzą autorzy słownika etymologicznego języka ukraińskiego, spotykany w ukraińskich dialektach rzeczownik бряск musiał do nich trafić z języka polskiego, o czym świadczy samogłoska [a] po miękkiej spółgłosce $[\mathrm{r}$ ] - na gruncie ukraińskim z [ē] powinno się tam rozwinąć [i]: діал. бряск ‘блиск, сяяння, зоріння, світанок’ (ESUM I: 273). Słownik etymologiczny języka polskiego autorstwa W. Borysia zawiera informację, że od XVI w. funkcjonuje w języku polskim forma brzask 'przedświt, rozwidnianie się, w dawnej polszczyźnie XV-XVII w. zaś używana była postać brzazg 'przedświt'. W. Boryś odwołuje się także do strus. brězgъ i psł. *brěskъ (Boryś 2008: 42). Nie ma raczej polskiej proweniencji użyty obok nazwanego rzeczownika czasownik, spokrewniony z pol. wierzgać, wierzgnać, niełączącymi się w polszczyźnie z przedstawioną zapożyczoną formą.

Онъ сясь нею вельбиль. - On miat z niq znajomość.

Słownik języka staroukraińskiego (ISUM III: 205) poświadcza funkcjonowanie formy велбити 'славити, прославляти, величати, возвеличувати', zestawiając ją z polskim wielbić. Również w słowniku W. Borysia stukr. velbiti 'wysławiać, wychwalać' jest przywołane jako zapożyczone z polskiego (Boryś 2008: 693). W słowniku tzw. warszawskim (Warsz.) znajdziemy szersze znaczenie leksemu wielbić 'wielkim a wielmożnym wyznawać, jako takiego wysławiać; uwielbiać, wynosić pod niebiosa, czcić, chwalić, ale także 'adorować, ubóstwiać, sławić'. To rozszerzenie poświadczają również wy-

${ }^{3}$ Najpewniej rezultatem stosowania pisowni etymologicznej jest fakt, że zapis leksemów z nowo zamkniętym [o] nie poświadcza przejścia tej głoski w [i]. 
razy pokrewne, np.: wielbiciel objaśnione m.in. jako 'adorator'; Wielbiciel jej wdzięków 'amant' (Warsz. VII: 565). Współczesny słownik języka polskiego znaczenie 'otaczać kogoś czcią i miłością; uwielbiać'; Wielbić wybranke swego serca, Wielbić piękno przyrody, stawia na pierwszym miejscu (SJP III: 702). W słowniczku I. Wahylewycza chodzi raczej o to właśnie znaczenie. W przeciwnym wypadku autor nie użyłby bowiem formy żeńskiej zaimka, co zdają się potwierdzać pozostałe zapisane przez niego przykłady. Warto zwrócić uwagę, iż zaszła tu transformacja czasownika przechodniego (ktoś wielbi kogoś) w czasownik zwrotny z dwoma podmiotami oddziałującymi na siebie nawzajem (ktoś wielbi się z kimś).

Не пильно ся д ветъ.-Nie potrzebuję.

Według autorów słownika etymologicznego języka ukraińskiego pochodzenie leksemu пильний nie jest do końca jasne, jednak są oni skłonni uznać jego polskie korzenie (ESUM IV: 369). Zaprezentowane w Idyotykonie połączenie wyrazów nie jest typowe ani dla języka polskiego, ani dla ukraińskiego.

\section{Плохій розумъ.-Lekkomyślność.}

Podobnego zestawienia wyrazów nie dokumentują ani ukraińskie, ani polskie źródła. Zapożyczony z języka polskiego został przymiotnik плохий, odnotowany m.in. w słowniku etymologicznym języka ukraińskiego, objaśniony jako 'поганий, кепський; не злий, не сварливий (про людину); спокійний, смирний; немічний, кволий...' Słownik ten klasyfikuje wspomniany leksem jako pożyczkę z języka polskiego, zestawiając go z pol. płochy 'легковажний; необачний, нерозважний; пустотливий; (заст.) полохливий; (ст.) незначний, дрібний'. Regularnie rozwinięta na ukraińskim gruncie jest forma полохливий, por. полохливий 'який лехко полохається' (SUM VII: 99); pokrewne полохати (ESUM IV: 454). Zwróćmy uwagę na fakt, iż polskie znaczenie przymiotnika już wiąże się z niestatecznym rozumem: płochy 'lekki, lekuchny; pierzchliwy; lekkomyślny' (Linde II, 2: 739); plochy 2. 'niestateczny, niestały, zmienny, pusty, lekkomyślny, wietrzny, trzpiotowaty, nierozważny, roztrzepany, narwany, swawolny'; płoche rozrywki, dni płoche itp. (Warsz IV: 258); płochy przest. 'niestały w uczuciach, rzadziej w poglądach; lekkomyślny, nierozważny’; płocha dziewczyna (SJP 1994, II: 699). 
Сей св вть пожитечный. - Ten świat doczesny.

Wariant tej frazy został poświadczony w zbiorku przysłów i porzekadeł galicyjskich H. Ilkewycza (Ількевич 1841), odnotowany jest również w pracy M. Nomysa (z powołaniem się na H. Ilkewycza) Сей світ позичений 'смерть' (Nomys 1993: 370). Słownik etymologiczny języka ukraińskiego dokumentuje formy зичити dial. жичити, жичати 'позичати' i klasyfikuje je jako pożyczki z języka polskiego (ESUM II: 263). Na polskie korzenie form позычати, позычєнїє i pod. wskazuje także słownik języka staroukraińskiego (SSM II: 176). Tenże słownik z polszczyzny wyprowadza również ukraiński leksem пожитокъ (stpol. pożytek, stczes. požitek) (SSM II: 173). Polskie słowniki etymologiczne wywodzą formę pożyczyć od pożytek, pożyteczny (Brückner 1985: 4330; Boryś 2008: 476). Interesująca jest rozbieżność znaczeń zaprezentowanego związku wyrazowego, podawanych w zbiorach ukraińskich, przy czym znaczenie udokumentowane przez I. Wahylewycza jest zrozumiałe ('świat doczesny = dany do używania, korzystania'; także z przymiotnikiem позичений 'dany pod warunkiem zwrotu'), natomiast zagadkowe wydaje się znaczenie odnotowane przez H. Ilkewycza i M. Nomysa. Żadne z wykorzystanych polskich źródeł nie dokumentuje podobnego połączenia wyrazów.

Пос встися не можеть зь радощій.-Bardzo sięcieszy.

Współczesne słowniki języka ukraińskiego poświadczają funkcjonowanie czasownika nосiдати 1 o przenośnym znaczeniu 'опановувати, охоплювати когось, оволодівати ким-, чим-небудь (про думки, почуття і т. ін.)', np.: його сум посідав, думки посідали Зінька (SUM VII: 328). Nie została jednak udokumentowana w ukraińskich źródłach forma zwrotna funkcjonująca w języku polskim, np.: nie posiadam się z radości 'nie jestem panem swoiey radości, jestem zachwycony, porwany nią, uniesiony' (Linde II, 2: 940); nie posiadać się z radości (Warsz. V: 464). ESUM (IV: 535) formę nocidamu i jej pochodne kwalifikuje jako kalkę z polskiego posiadać lub/i czeskiego posednouti.

Пречь бы ся казало (тякло).-Obyo tem nie wspominać.

Podobne jednostki zostały utrwalone w ukraińskich zbiorach paremiologicznych mieszczących materiał zebrany w XIX w.: Преч би сї казало! 
$($ Кол.) = вар. до най сі преч каже. Нехай ся пріч каже. (Ільк.), оbјаśnione jako formuła odpędzania złej siły (Franko XXIV: 588; Nomys 1993: 374); Най преч ся каже bez objaśnień (Franko XXVIII: 512). Równocześnie wśród jednostek zebranych przez I. Frankę zostały zamieszczone frazy: Бодай не казати! Говорять згадуючи щось страшне або прикре (Franko XXIII: 236); Щоби нічого не казати! (Лучак) Коли мова зійде на якусь прикру річ, яку бесїдник волить промовчати (Franko XXIII: 236). I to właśnie znaczenie przypisał I. Wahylewycz w swym słowniczku omawianemu powiedzeniu. Interesująca jest sama forma преч 'геть', którą słownik etymologiczny określa jako zapożyczenie z języka polskiego, mające związek z ukraińską formą npiu (ESUM IV: 568). Dokładniejszą informację o ich pochodzeniu znajdujemy w słowniku W. Borysia, który wyjaśnia, iż wyrazy wschodniosłowiańskie, srus. pročъ 'precz', r. proč' 'oprócz', ukr. prič 'prócz; oprócz', kontynuują psł. *proč 'poza, dalej', używane też w funkcji wykrz. 'precz!', od psł. przym. *prokъ 'oddalony, stojący obok'. Natomiast pol. precz autor wywodzi od niezbyt jasnej według jego słów prapostaci *prъčb z prawdopodobnie wtórnym $z$ (Boryś 2008: 482). Wart uwagi jest fakt, że większość poświadczonych w ukraińskich zbiorach paremiologicznych wariantów zaprezentowanej formuły zawiera formę z [e] (choć u I. Wahylewycza może to być efektem błędnie zastosowanej pisowni etymologicznej).

Онь сило-моцью тото взяль.-On gwaltem to wziqt.

Etymologiczny słownik języka ukraińskiego formę мiųь i dial. мou, моца 'сила, міцність, могутність' oraz dawną моџь 'спроможність, сила, чинність; збройні сили’ objaśnia jako dawne pożyczki z języka polskiego, odpowiadające archaicznemu ukraińskiemu rzeczownikowi міч 'сила, змога', spokrewnionemu z могти (ESUM III: 487). Liczne formy rzeczownika міцьь, моu i jego pochodnych zostały utrwalone w słowniku języka staroukraińskiego (SSM I: 615). Użyta w analizowanej jednostce słownikowej forma przysłówka сило-моцью шуraźnie odpowiada współczesnym ukraińskim formom potocznym силоміцьь, силоміџџю 'проти волі, насильно' (SUM IX: 169). Słownik etymologiczny wywodzi przysłówek силоміць, силоміцию (dial. силоміть) od formy dial. силоміття (силоміть 'насильство'), utworzonej, jak przypuszczają autorzy słownika, z połączenia rzeczownika сила i czasownika *(ü) міти 'wziąć'; według nich od adwerbializowanej formy narzędnika *силоміттю poprzez zbliżenie z tematem міu̧ь mogła zostać utworzona 
forma силоміцию і analogicznie do піеј силоміць (ESUM V: 230); por. dial. іміти, иміти, міти 'мати', иметти (ESUM II: 298). Być może warto jednak zastanowić się, czy nie mamy tu raczej do czynienia ze swoistą tautologią. Porównajmy polską adwerbializowaną formę moca 'gwałtem, przemocą, notowaną np. w słowniku Lindego (Linde III: 128), czy rejestrowaną jako przestarzała w słowniku tzw. warszawskim (Warsz. II: 1020) i ukraińską postać силою 'насильно' (SUM IX: 170). Nadmieńmy, że użycie narzędnika rzeczownika сила w tym znaczeniu poświadczają przykłady przywoływane w słowniku języka staroukraińskiego (SSM II: 343), a próżno w nim szukać formy силоміття сzу силоміть; por. сила 4. 'насильство, примус' (tamże). Źródło to dokumentuje również ustalone połączenia wyrazowe приходитu моцью, приходити силою 'вдиратися силою, насильно' (SSM II: 250). Por. nierzadkie w języku ukraińskim formacje typu: рано-вранці, без кіния-краю, мало-помалу, часто-густо, неждано-негадано; дуже-дуже, далекодалеко i pod. W takim wypadku to dial. силоміття (силоміть) mogłoby powstać poprzez zbliżenie z tematem мim $\mathrm{w}$ wyniku analogii do form typu ximbне-хіть, самохіть, мимохіть, доброхіть, ледь-ледь, навкидь, заздалегідь, мимохідь, впроголодь, сzу tеż знаття, биття, життя, лиття, молоття, прибуття i pod.

Не заходи си съ нимъ.-Nie zaczepiaj sięz nim.

Słowniki dawnej polszczyzny rejestrują funkcjonowanie form zachodzić się, zajść się 'kłócić się, wejść w zatarg', np.: Z takowemi ludźmi trudno się komu zgodzić, którzy leda o naymnieyszq rzecz swarzq się a zachodzq (Linde IV: 831); A ten przyjaciel wacpani czy wie, jakośmy daleko z sobq zaszli? 'posunęli się, zaawanturowali się, postąpili' (Warsz. VIII: 114); takie ich użycie pośrednio poświadcza również istnienie w języku polskim spokrewnionego z nimi rzeczownika zajście 'wydarzenie, w którym dochodzi do konfliktu; incydent, awantura, zatarg' (SJP III: 912). Ukraiński czasownik заходитися ma znaczenie 'починати що-небудь робити', 'задихатися, захлинатися' itp. (SUM III: 386-389). Za używaniem tego czasownika w znaczeniu odnotowanym przez I. Wahylewycza może jedynie przemawiać dialektalna forma зайденний 'сердитий, запальний', zaczerpnięta do słownika etymologicznego z rejestru D. Jawornickiego (ESUM II: 320) - znaczenie to może jednak być powiązane z заходитися ‘дуже сильно, захлинаючись, кричати’ itp. 
Туча збила збоже.- Grad zniszczył zboże.

Polską proweniencję ma forma збоже używana w starych tekstach ukraińskich (SSM I: 389). Ukraiński regularnie rozwinięty odpowiednik zawiera wzdłużenie spółgłoski szeleszczącej (збіжжя). Inne formy, które we współczesnym ukraińskim języku literackim mają wzdłużone spółgłoski (II deklinacja r. n.), w Idyotykonie i Idyotyzmach zostały zapisane z końcowym -be, nр.: волосье, молчанье, роспутье, чутье; a spora ich ilość posiada wygłosowe -iе, nр.: веселіе, оружіе, понятіе, усиліе; wyjątkiem jest forma убочьа. Zapisy te (oprócz ostatniego, odzwierciedlającego formę dialektalną) są zgodne z pisownią historyczną wymienionych rzeczowników.

Жона его зи плеча.-Żona jego z dobrego doти.

Prawdopodobnie jest to zapożyczenie z polszczyzny. Ukraiński słownik frazeologiczny notuje wprawdzie jednostkę з плеча, jednak z zupełnie innym znaczeniem: 1. з сл. вдаряти, бити і т. ін. 'навідліг, з розмаху', 2. $з$ сл. говорити, вирішувати і т. ін. 'не подумавши, зразу'. 3 чужого плеча 'невідповідний за розміром або вже ношений ким-небудь іншим (про одяг)' (FSUM II: 646). Również wykorzystane słowniki języka polskiego nie poświadczają takiego połączenia wyrazowego, jednak dawne polskie formy rzeczownika plec, plece, a także plecy są odnotowywane w polskich słownikach ze znaczeniem, które wiąże się z siła, możnością, znaczącym rodem. Por. np.: plec 'siła, moc, przemaganie', po plecach to moich 'zdołam temu', po plecu czyim bydź, po plecach czyich bydź 'podpierać go, wspierać go, iego stronę trzymać, z iego strony bydź' (Linde II, 2: 732); plece 2. 'siła, moc, możność'. 3. plecy przen. 'poparcie, protekcja'. 4. po plecu czyim być, po plecach czyich być (przest.) 'być jego poplecznikiem, stronnikiem, trzymać jego stronę, być po jego stronie, popierać go' (Warsz. IV: 227); por. współczesne pol. mieć plecy, poplecznik. W przypadku ukr. плече brak jest takiego znaczenia. W słowniku etymologicznym języka ukraińskiego odnotowano tylko dial. поплечник і поплічник 'помічник; прихильник, послідовник', które muszą się wywodzić z polskiego ( cach itp.); por. notowane w słowniku etymologicznym jezzyka ukraińskiego: ukr. dial. поплеч 'поруч, поряд'; попліч 'т.с., пліч-о-пліч'; діал. поплічний 'рівний, однаковий' і inne znaczenie formy поплічник 'ровесник; той, що несе на плечах' (ESUM IV: 442). W słowniku współczesnym udoku- 
mentowano związki wyrazowe вiдчувати плече 'мати чиюсь підтримку, допомогу, усвідомлювати свою єдність з ким-небудь' oraz спиратися на плече (чиє) 'знаходити в кому-небудь підтримку, допомогу' (SUM VI: 580). Nazwane źródło zamieszcza również jednostkę мати плечi (за собою) ‘бути під чиїм-небудь захистом; мати чиюсь протекцію’ (SUM VI: 580), powołując się jednak na galicyjskiego autora I. Frankę.

Głębsza analiza większej ilości dawnych tekstów być może pozwoli na wyodrębnienie innych elementów polskiego pochodzenia w badanym materiale. Jak zostało wspomniane wyżej, fakt, że analizowany zbiór I. Wahylewycza razem z Idyotykonem stanowi dodatek ilustrujący do Rozpraw... tegoż badacza, pozwala zakładać, iż leksykograf starał się w nim pokazać, że odnotowane przez niego jednostki są charakterystyczne dla języka ukraińskiego. Zdziwienie jednak budzi w czytelniku dobór części materiału i „tłumaczenie" przez autora niektórych konstrukcji na język polski oraz unikanie bliskobrzmiących form i sformułowań w polskim materiale, gdyż obeznany świetnie z polszczyzną I. Wahylewycz znał zapewne owe polskie odpowiedniki. Oprócz jednostek przywoływanych w powyższej analizie bliskie i zrozumiałe dla Polaków są liczne inne zawarte w zbiorze konstrukcje, takie jak np.: Въ голову захожу. - Nie umiem sobie poradzić; Здался на право. - Udat sie do sqdu; Мене ся тото не тичитъ. - то do mnie nie należy; Не льзъ му въ очи. - Nie dokuсzaj ти; Онъ ся затяль. - On sie zawziat; Пойтоль безъ въсти. - Poszedt nie wiedzieć gdzie; Я ти не скажу. - Nie umiem ci powiedzieć, itp. Właśnie przyjęta przez I. Wahylewycza metoda stworzenia słownika po pierwszym zetknięciu z nim intryguje i skłania do wysunięcia przedwczesnego wniosku, że rejestr ten jest pełen polonizmów. Gruntowniejsze przebadanie materiału wykazuje jednak, że większa część odnotowanych przez lwowskiego badacza jednostek rozwinęła się najprawdopodobniej na rodzimym gruncie bądź też trudno taką możliwość wykluczyć. Autorowi nie udało się jednakże uniknąć zawarcia w swym zbiorze elementów zapożyczonych z języka polskiego, w pewnych sytuacjach zapewne nieświadomie. Część przedstawionych powyżej polonizmów stanowią proste zapożyczenia semantyczne lub formalnosemantyczne, jednak najciekawsze z zaprezentowanych przykładów są te, które obrazują zmianę formy zapożyczonej jednostki lub zmianę jej łączliwości. W kilku wypadkach autor raczej musiał być świadom polskich korzeni komponentów odnotowanych frazeologizmów - być może sporządzając swe zestawienie charakterystycznych 
ukraińskich połączeń wyrazowych, chciał on uzmysłowić czytelnikom, jakie zmiany przeszły pochodzące z języka polskiego jednostki po zadomowieniu się w dialektach ukraińskich.

\section{Bibliografia}

Bą S., Mayenowa M. R., Pepeowski F. (red.), Stownik polszczyzny XVI wieku, 1966-, t. 1-(31) [online], http://kpbc.umk.pl/publication/17781, [09. 2009].

Boryś W., 2008, Stownik etymologiczny języka polskiego, Kraków: Wydawnictwo Literackie.

BRÜCKner A., 1985, Stownik etymologiczny języka polskiego, Warszawa: Wiedza Powszechna.

ДзЕндзЕлівський Й., 1981, Іван Вагилевич і словник С.Б. Лінде, Prace Filologiczne 30, s. 143-158.

ДзЕндзЕлІвський Й., 2000, І. Вагилевич - перший дослідник іншомовних запожичень в українській мові: переймання зі слов'янських мов, Studia z filologii polskiej i stowiańskiej 36, s. 157-177.

ДзЕндЗЕлІвський Й., 1979, Українсько-польський фразеологічний словник Івана Вагилевича, Studia z filologii polskiej i stowiańskiej 18, s. 177-184.

ESUM = Мельничук О. С., та інші (red.), Етимологічний словник украйнської мови, 1982-, t. 1-(7), Київ: Наукова Думка.

Франко I., 1901-1910, Галицько-руські приповідки, (Етнографічний збірник НТШ X, XIV, XXIII, XXIV, XXVII, XXVIII), Львів.

FSUM = Білоноженко В. М., Винник В. О., та інші, Фразеологічний словник украӥнської мови, 1999, t. 1-2, Київ: Наукова Думка.

Ількевич Г., 1841, Галищькі приповідки $і$ загадки, Відень: Друкарня о.о. Мехитаристів.

ISUM = Гринчишин Д. (red.), Словник української мови XVI - першої половини XVII cm., 1994-, у 28 випусках, Львів: Наукове товариство імені Шевченка у Львові.

KarŁowicz J., 1900-1911, Stownik gwar polskich [online], http://www.pbi.edu.pl/ site.php?s=MzE2NTM5YWYwOTY4\&tyt $=\mathrm{s} \% \mathrm{C} 5 \% 82$ ownik + gwar\&aut $=\& \mathrm{x}=0$ $\& y=0,[09.2009]$.

Linde S. B., 1807-1814, Stownik języka polskiego, t. 1-6, [online], http://kpbc.umk. $\mathrm{pl} / \mathrm{dlibra} /$ publication$? \mathrm{id}=8173 \&$ from $=$ plannedpubssearch $\&$ dirids $=1 \& \operatorname{tab}=1$, [09.2009].

Nомүs, Номис М., 1993, Українські приказки, прислів’я і таке інше, Збірники О. Марковича та інших, уклав М. Номис, Київ: Либіgь. 
Онишкевич М., 1984, Словник бойківських говірок, t. 1-2, Київ: Наукова Думка.

WaGilewicz I., 1845, Grammatyka języka małoruskiego w Galicii, Lwów: Instytut Stauropigiański.

ВАГилевич I., 1978, Бойки, рускослов'янський люд у Галичині, Жовтень 12, S. $112-130 \mathrm{I}$.

ВАГилевич I., 1965, Лемки - мешканці західного Прикарпаття, Народна творчість та етнографія 4, s. 76-80.

Wahylewič Dalibor J., 1841, Bojkowé, lid ruskoslowanský w Haličjeh, Časopis českého Museum 1, Praha, s. 30-72.

(WAhylewycz I.), 1842, Гуцули. Карпатские горцы, Сын Отечества 3, s. 1-33.

(WAHYLEWYCZ I.), 1855, Гуцули, обидатели восточной отрасли Карпатских гор, Пантеон XXI, 5, s. 17-56.

(WAhylewycz I.), 1838-1839, Huculové, obywatele vychodňiho pohoži karpatskeho, Časopis českého Museum, Praha, s. 475-498 (1838); s. 45-68 (1839).

(Wahylewycz I.), 1844, O mieszkańcach Wschodniej Części gór Karpackich, Przeglad Naukowy 2, nr 15, s. 161-177; Przeglad Naukowy 4, nr 28, s. 16-27; nr 29, s. 48-60; nr 30, s. 73-85.

(WAhylewycz I.), Idyotykon, Oddział rękopisów Biblioteki RAN w Petersburgu, sygn. [собр. А. С. Петрушевича, № 22-23].

(WAhylewycz I.), Idyotykon, Oddział rękopisów Biblioteki UAN im. W. Stefanyka we Lwowie, sygn. [Ваг. 55. п. 16].

(WAhylewycz I.), Rozprawy o języku południowo-ruskim, Oddział rękopisów Biblioteki RAN w Petersburgu, sygn. [собр. А.С. Петрушевича, № 22].

WArSz. = Karłowicz J., Kryński A., Niedźwiedzki W. (red.), Słownik języka polskiego, 1900-1927, t. 1-8, [online], http://ebuw.uw.edu.pl/dlibra/publication?id=254, [09.2009].

СЕмчинский С., 1970, Элементы венгерского происхождения в „Дакийском словаре” Ивана Вагилевича, Slavica 10, Debrecen, s. 115-121.

СЕмчинський С., 1970, Фонетичні особливості „Дакійського словника” I. М. Вагилевича, Вісник Киїського університету 12, Сер. філол., s. 44-51.

$\mathrm{SJP}=$ Szymczak M. (red.), Słownik języka polskiego, 1994, t. 1-3, Warszawa: PWN.

$\mathrm{SSM}=$ Гумецька Л. Л., Керницький I. М., Словник староукраӥнської мови XIV-XV cm., 1977, t. 1-2, Київ: Наукова Думка.

SUM = Словник украӥнської мови, 1970-1980, t. 1-11, Київ: Наукова Думка. 


\section{Польские заимствования в украинском материале украинско-польского фразеологического словаря XIX в. Ивана Вагилевича}

( р е $з$ ю м е)

В статье анализируются заимствования из польского языка, зафиксированные в украинско-польском фразеологическом словаре XIX в. И. Вагилевича (Idyotyzmy). Часть из них - это простые формально-семантические заимствования. Среди прочих наиболее интересны те, в которых можно отметить изменения, коснувшиеся заимствованной единицы или ее сочетаемости. В некоторых случаях исследователь осознавал, что компоненты фразеологизмов имеют польские корни. Сопоставляя их с типичными украинскими выражениями, возможно, он хотел показать, какие изменения произошли в единицах польского происхождения после того, как прижились в украинских говорах. Однако озадачивает то, что автор, который великолепно знал польский язык, избегает представления созвучных эквивалентов в польском языковом материале. 